Prepared in cooperation with the Idaho Department of Environmental Quality

\title{
Groundwater Quality and Nutrient Trends near Marsing, Southwestern Idaho, 2018
}
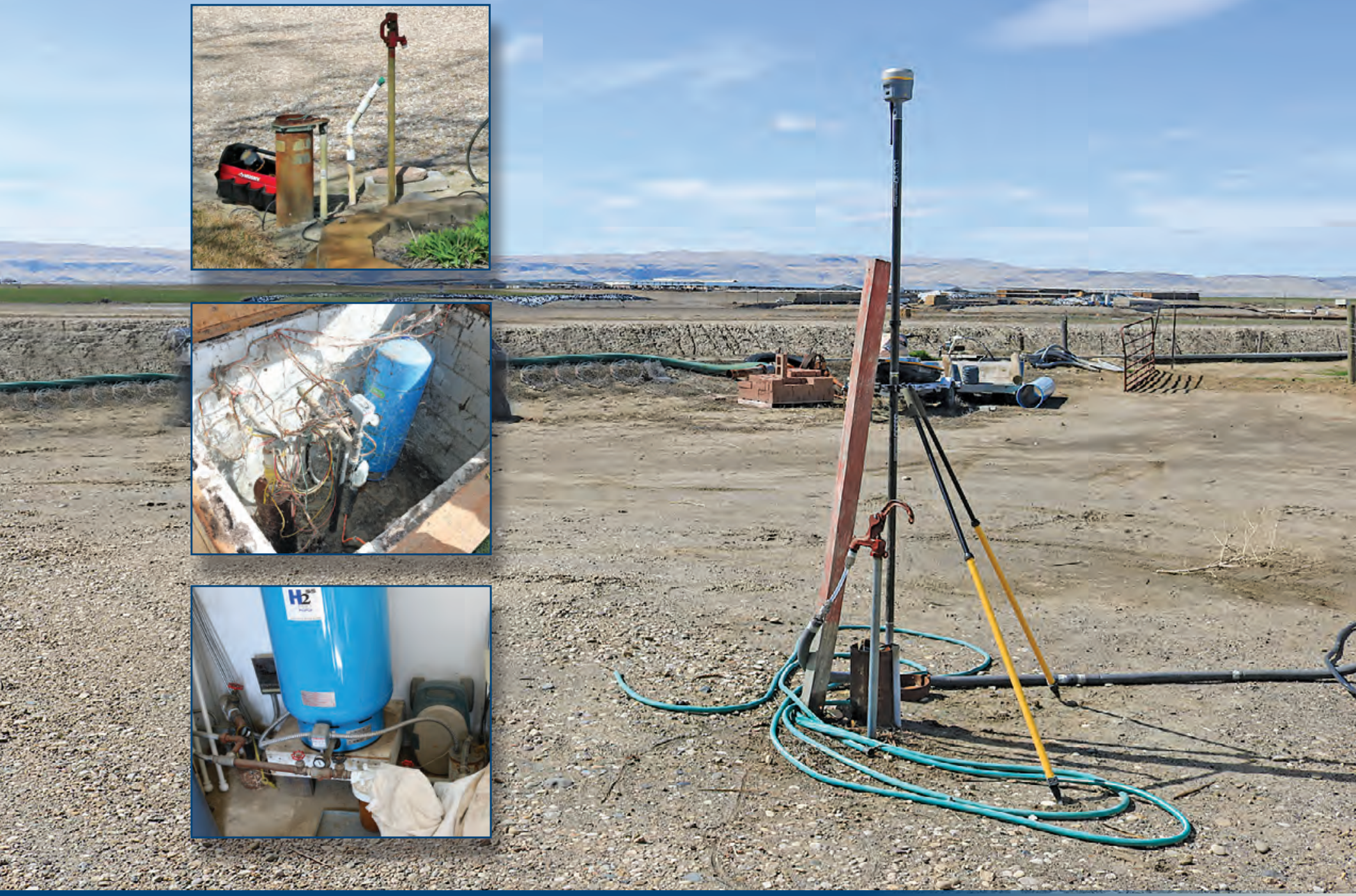

Open-File Report 2019-1032

U.S. Department of the Interior

U.S. Geological Survey 
Cover: Main image: Groundwater quality sampling, level measurement, and elevation survey at well 433449116504401, Marsing, Idaho, March 27, 2018. Photograph by Kenneth Skinner, U.S. Geological Survey.

Upper inset picture: Groundwater quality sampling, level measurement, and elevation survey at well 433322116515601, Marsing, Idaho, March 28, 2018. Photograph by Kenneth Skinner, U.S. Geological Survey.

Middle inset picture: Groundwater quality sampling, level measurement, and elevation survey at well 433441116511201, Marsing, Idaho, April 3, 2018. Photograph by Kenneth Skinner, U.S. Geological Survey.

Lower inset picture: Three wells including well 433515116524601 used for groundwater quality sampling and elevation survey, Marsing, Idaho, March 28, 2018. Photograph by Kenneth Skinner, U.S. Geological Survey. 


\section{Groundwater Quality and Nutrient Trends near Marsing, Southwestern Idaho, 2018}

By Kenneth D. Skinner

Prepared in cooperation with the Idaho Department of Environmental Quality

Open-File Report 2019-1032

U.S. Department of the Interior

U.S. Geological Survey 


\title{
U.S. Department of the Interior DAVID BERNHARDT, Acting Secretary
}

\author{
U.S. Geological Survey \\ James F. Reilly II, Director
}

U.S. Geological Survey, Reston, Virginia: 2019

For more information on the USGS-the Federal source for science about the Earth, its natural and living resources, natural hazards, and the environment-visit https://www.usgs.gov/ or call 1-888-ASK-USGS (1-888-275-8747).

For an overview of USGS information products, including maps, imagery, and publications, visit https://store.usgs.gov/.

Any use of trade, firm, or product names is for descriptive purposes only and does not imply endorsement by the U.S. Government.

Although this information product, for the most part, is in the public domain, it also may contain copyrighted materials as noted in the text. Permission to reproduce copyrighted items must be secured from the copyright owner.

Suggested citation:

Skinner, K.D., 2019, Groundwater quality and nutrient trends near Marsing, southwestern Idaho, 2018: U.S. Geological Survey Open-File Report 2019-1032, 23 p., https://doi.org/10.3133/ofr20191032.

ISSN 2331-1258 (online) 


\section{Contents}

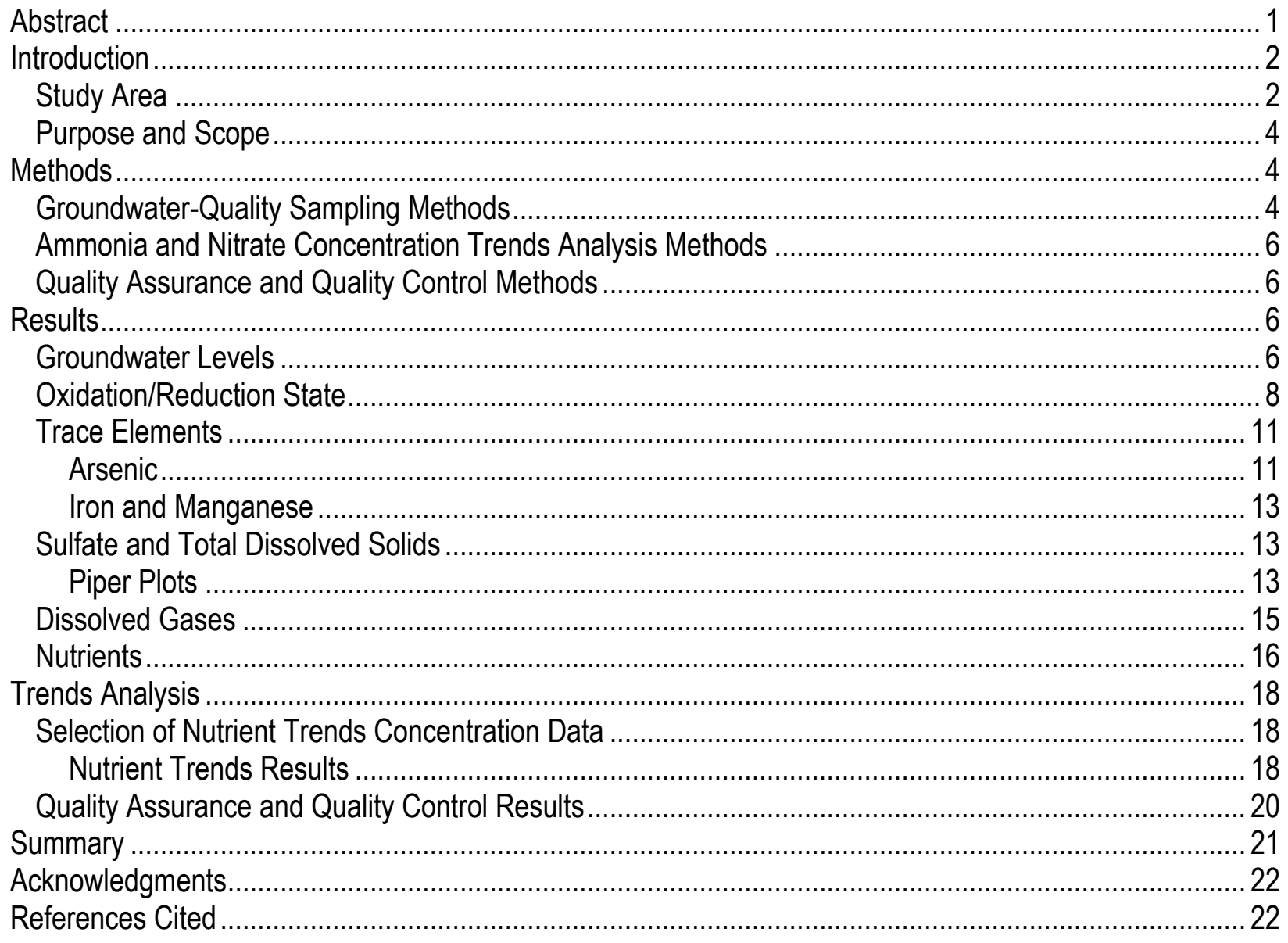

\section{Figures}

Figure 1. Map showing the study area and site identification numbers for 15 wells sampled near Marsing, southwestern Idaho, 2018.

Figure 2. Map showing groundwater potentiometric surface and flow direction derived from nine groundwater-level measurements near Marsing, southwestern Idaho, 2018

Figure 3. Map showing groundwater-quality sampling locations with site identification numbers and oxidation/reduction process and type for 15 wells near Marsing, southwestern Idaho, 2018.

Figure 4. Arsenic concentrations from 15 water-quality samples collected from wells near Marsing, southwestern Idaho, 2018.

Figure 5. Map $(A)$ and piper plot $(B)$ of 15 groundwater-quality samples collected near Marsing, southwestern Idaho, 2018.

Figure 6. Map showing dissolved oxygen presence and nutrient type in groundwater-quality samples from 15 wells near Marsing, southwestern Idaho, 2018.

Figure 7. Graphs showing ammonia and nitrate concentrations from water-quality samples collected at well 433422116511601 near Marsing, southwestern Idaho, 2018. 


\section{Tables}

Table 1. Groundwater-quality parameters sampled from 15 wells near Marsing, southwestern Idaho, 2018.

Table 2. Oxidation/reduction (redox) state and predominant process, with selected groundwater-quality results from 15 wells near Marsing, southwestern Idaho, 2018.

Table 3. Ammonia and nitrate trend evaluations from water-quality samples collected at 15 wells near

Marsing, southwestern, Idaho, 2018

\section{Conversion Factors}

International System of Units to U.S. customary units

\begin{tabular}{lcl}
\hline \multicolumn{1}{c}{ Multiply } & By & \multicolumn{1}{c}{ To obtain } \\
\hline liter (L) & Volume & \\
liter (L) & 33.81402 & ounce, fluid (fl. oz) \\
liter (L) & 2.113 & pint (pt) \\
liter (L) & 1.057 & quart (qt) \\
cubic centimeter $\left(\mathrm{cm}^{3}\right)$ & 0.2642 & gallon (gal) \\
cubic decimeter $\left(\mathrm{dm}^{3}\right)$ & 0.06102 & cubic inch $\left(\mathrm{in}^{3}\right)$ \\
liter (L) & 61.02 & cubic inch $\left(\mathrm{in}^{3}\right)$ \\
\hline & 61.02 & cubic inch (in $\left.{ }^{3}\right)$ \\
\hline gram (g) & Mass & \\
\hline
\end{tabular}

Temperature in degrees Celsius $\left({ }^{\circ} \mathrm{C}\right)$ may be converted to degrees Fahrenheit $\left({ }^{\circ} \mathrm{F}\right)$ as:

$$
{ }^{\circ} \mathrm{F}=\left(1.8 \times{ }^{\circ} \mathrm{C}\right)+32 .
$$

\section{Datum}

Vertical coordinate information is referenced to the North American Vertical Datum of 1988 (NAVD 88).

\section{Supplemental Information}

Specific conductance is given in microsiemens per centimeter at 25 degrees Celsius $\left(\mu \mathrm{S} / \mathrm{cm}\right.$ at $\left.25^{\circ} \mathrm{C}\right)$.

Concentrations of chemical constituents in water are given in either milligrams per liter $(\mathrm{mg} / \mathrm{L})$ or micrograms per liter $(\mu \mathrm{g} / \mathrm{L})$.

\section{Abbreviations}

EPA U.S. Environmental Protection Agency

IDEQ Idaho Department of Environmental Quality

ISDA Idaho State Department of Agriculture

MCL maximum contaminant level (EPA)

NWQL National Water Quality Laboratory (USGS)

SMCL secondary maximum contaminant level (EPA)

USGS U.S. Geological Survey 


\title{
Groundwater Quality and Nutrient Trends near Marsing, Southwestern Idaho, 2018
}

\author{
By Kenneth D. Skinner
}

\begin{abstract}
The U.S. Geological Survey, in cooperation with the Idaho Department of Environmental Quality, sampled groundwater from 15 wells during spring 2018 near the city of Marsing in rural northwestern Owyhee County, southwestern Idaho. Samples were analyzed for field parameters, nutrients, trace elements, major inorganics, and dissolved gas, including methane. To examine trends in individual wells and in the region, ammonia and nitrate results from the spring 2018 sampling were compared with data collected from 1996 to 2015 by the Idaho Department of Environmental Quality and the Idaho State Department of Agriculture.

Fourteen of the 15 samples collected in 2018 contained arsenic (0.13-33.8 micrograms per liter $[\mu \mathrm{g} / \mathrm{L}])$, with 7 arsenic concentrations greater than the U.S. Environmental Protection Agency (EPA) maximum contaminant level (MCL) of $10 \mu \mathrm{g} / \mathrm{L}$. Iron $(465-4,180 \mu \mathrm{g} / \mathrm{L})$, manganese $(54-693 \mu \mathrm{g} / \mathrm{L})$, sulfate (300-624 milligrams per liter [mg/L]), and total dissolved solids $(511-1,350 \mathrm{mg} / \mathrm{L}) \mathrm{were}$ detected at concentrations greater than EPA secondary maximum contaminant levels (SMCL) in waterquality samples from $6,10,4$, and 14 of the 15 wells, respectively. Fourteen of the 15 samples contained ammonia concentrations from 0.12 to 7.34 milligrams per liter $(\mathrm{mg} / \mathrm{L})$. Six samples contained nitrate concentrations from 0.08 to $24.6 \mathrm{mg} / \mathrm{L}$, with one sample greater than the EPA MCL of $10 \mathrm{mg} / \mathrm{L}$ for drinking water. The presence of both ammonia and nitrate in four samples indicated multiple nutrient and groundwater sources and varying redox states. Ammonia concentrations tended to increase downgradient throughout the study area.

Nutrient trend analysis identified water-quality samples from 2 of the 15 wells with increasing nitrate concentrations from 1999-2018 and 2005-2018. The well with increasing nitrate concentrations from 2005-2018 showed a decreasing trend in ammonia concentrations during the same time period. Groundwater-quality samples from the 13 remaining wells showed no temporal trends. A Regional Kendall test, which evaluates trends at numerous wells across the study area to determine if a consistent trend exists for the area, was done to analyze 539 ammonia concentrations from 91 wells over 20 years (1999-2018) and 591 nitrate concentrations from 107 wells over 23 years (1996-2018). The Regional Kendall Test for ammonia had a tau correlation coefficient of -0.073 with a p-value of 0.072 , and nitrate had a tau correlation coefficient of -0.041 with a p-value of 0.198 , both indicating no statistically significant trends.
\end{abstract}




\section{Introduction}

In March 1999, the Idaho Department of Environmental Quality (IDEQ) and the Idaho State Department of Agriculture (ISDA) initiated a cooperative, 5-year study of groundwater quality in northwestern Owyhee County near the town of Marsing, southwestern Idaho. The study was prompted by citizens' concerns about increased dairy operations in the area and by previous detections of elevated concentrations of nitrate in groundwater. The study identified several water-quality parameters of concern, including nitrate, chloride, sulfate, arsenic, and specific conductance. As the study progressed, IDEQ and ISDA continued sampling groundwater, well owners became more aware of groundwater quality issues, and the ISDA updated waste containment rules and created nutrient management plans (Boyle and others, 2002).

A subsequent 10-year ISDA study from 1999 to 2008 (Bahr, 2009) indicated that the shallow alluvial aquifer was being impacted by nitrate and pesticides and detected elevated ammonia concentrations in the deeper aquifer. During the 10 years of sampling, 4-12 percent of the wells sampled had nitrate concentrations greater than 10 milligrams per liter $(\mathrm{mg} / \mathrm{L})$, the U.S. Environmental Protection Agency (EPA) maximum contaminant level (MCL). The ISDA study also reported stable nitrate and ammonia concentrations during the 10-year study period. Nitrogen isotope results suggested that fertilizer and animal waste were sources of nitrate. The ISDA study recommended additional groundwater-quality sampling and implementing measures to reduce nutrient impacts on groundwater such as evaluating nutrient management plans for all agricultural types in the area, growers, agrichemical professionals, and dairy and feedlot facilities.

\section{Study Area}

The study area is located near Marsing in rural northwestern Owyhee County (fig. 1). The study area is bordered to the north and east by the Snake River, to the south by State Highway 55, and to the west by Jump Creek (fig. 1). The topography in the study area is predominantly flat, sloping gently towards the Snake River. The area is used primarily for agriculture, with irrigated alfalfa fields and large concentrated dairy farms (Idaho Department of Environmental Quality, 2010). The predominant crops in the area are corn, alfalfa, and wheat (U.S. Department of Agriculture, 2018). 


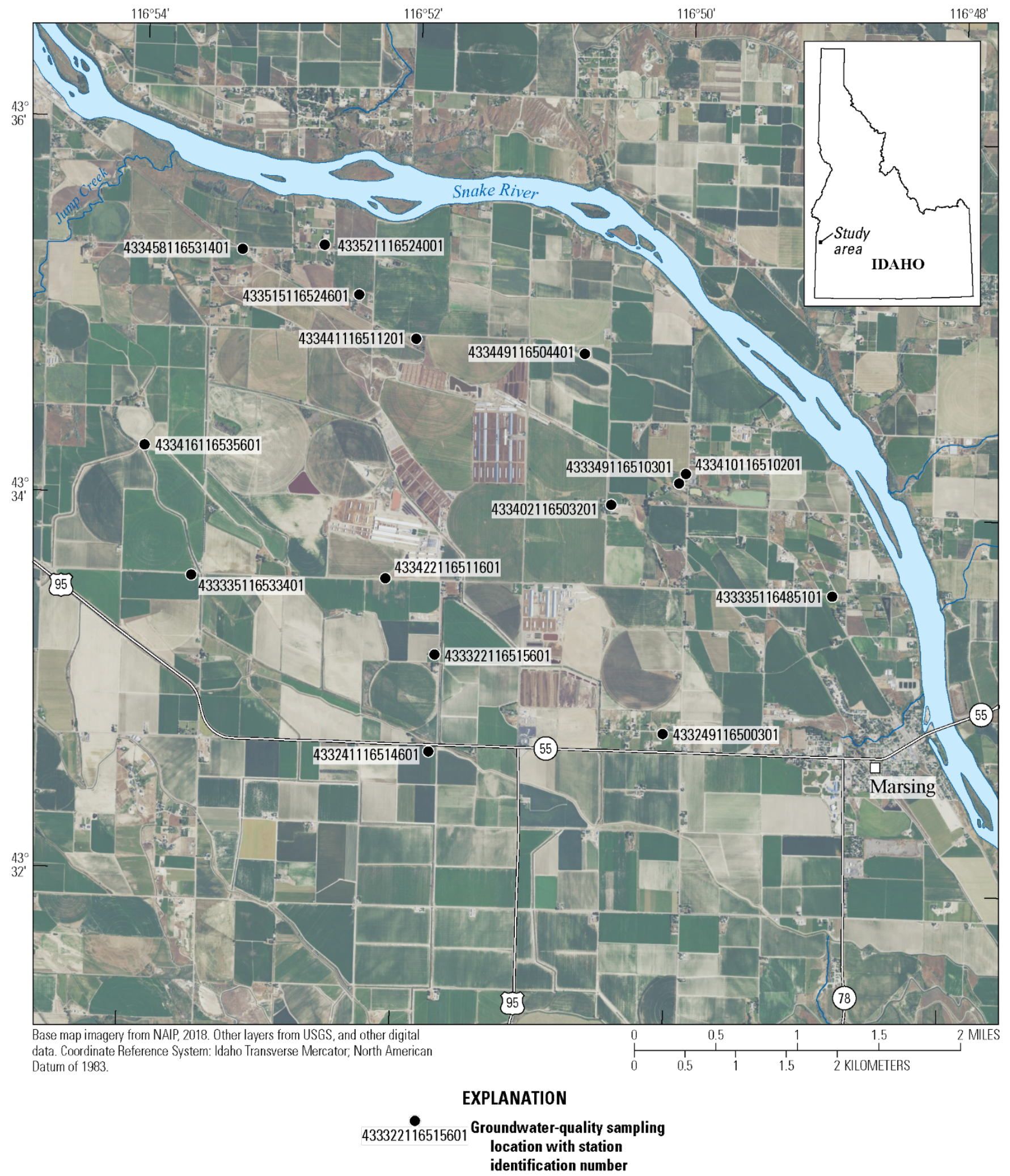

Figure 1. Map showing the study area and site identification numbers for 15 wells sampled near Marsing, southwestern Idaho, 2018. 
The geologic map of Owyhee County indicates the study area is made up of Quaternary gravels and terraces on western Snake River Plain with Quaternary alluvial deposits along the Snake River (Link, 2002). Groundwater primarily occurs within fractured basalt, with sedimentary sequences of gravel, sand, silt, and clay (Idaho Department of Environmental Quality, 2010).

Most residents in the study area rely on domestic wells for water and are on septic systems. Domestic wells in the area have typical water uses, such as bathing, washing, and watering yards and gardens. Many of the residents do not use water from their wells for drinking due to aesthetic issues such as a strong sulfur smell.

\section{Purpose and Scope}

This report documents groundwater-quality sampling at 15 wells near Marsing, Idaho, in southwestern Idaho, during spring 2018. The sampling was done to assess groundwater quality in the area.

This report also evaluates nutrient trends and provides the data necessary for future trend analyses of nutrients and other contaminants of interest. This report focuses on the occurrence and trends of ammonia and nitrate in groundwater. Any groundwater quality parameters greater than EPA MCL or secondary maximum contaminant levels (SMCLs) are also discussed.

\section{Methods}

\section{Groundwater-Quality Sampling Methods}

At each well, the same methods were used to document, survey, sample, and measure the groundwater level. Upon arrival at a well, photographs were taken to document the setting and any possible nearby sources of contamination. If possible, the location and altitude of the well were surveyed, and the groundwater level was measured following the procedures of Cunningham and Schalk (2011).

Groundwater-quality sampling followed U.S. Geological Survey (USGS) protocols for collecting water-quality data (U.S. Geological Survey, variously dated), including specific methods for determining adequate well purge prior to sampling, such as flushing at least three well bore volumes of water prior to sampling and monitoring filed parameters until stabilized (Wilde, 2006). Most sites sampled in this study are heavily used domestic wells. The wells were purged for a minimum of 25 minutes prior to sampling. Field parameters $(\mathrm{pH}$, water temperature, specific conductance, dissolved oxygen, and turbidity) were measured every 5 minutes until they became stable, indicating adequate well purge. Once the well purge was completed, groundwater was transferred directly from the well faucet to a mobile laboratory through Teflon ${ }^{\circledR}$ tubing, and all samples were collected in an isolated processing chamber where sampling occurred. When sampling was completed, samples were preserved if required and shipped overnight to the USGS National Water Quality Laboratory (NWQL) in Lakewood, Colorado, except samples for dissolved gas analysis. Five dissolved gas samples were collected and stored in a cool dark place until sampling was complete, and then samples were shipped to the Isotech Laboratory in Champaign, Illinois. A complete list of sampled constituents is shown in table 1 . 
Table 1. Groundwater-quality parameters sampled from 15 wells near Marsing, southwestern Idaho, 2018.

[Reporting levels for field parameters determined using U.S. Geological Survey National Field Manual protocols. All other reporting levels determined from analyses of samples at the laboratory indicated in that constituent's spanner.

Abbreviations: $\mathrm{mg} / \mathrm{L}$, milligram per liter; $\mu \mathrm{g} / \mathrm{L}$, microgram per liter; $\mu \mathrm{S} / \mathrm{cm}$ at $25^{\circ} \mathrm{C}$, microsiemens per centimeter at 25 degrees Celsius; cc/L, cubic centimeter per liter]

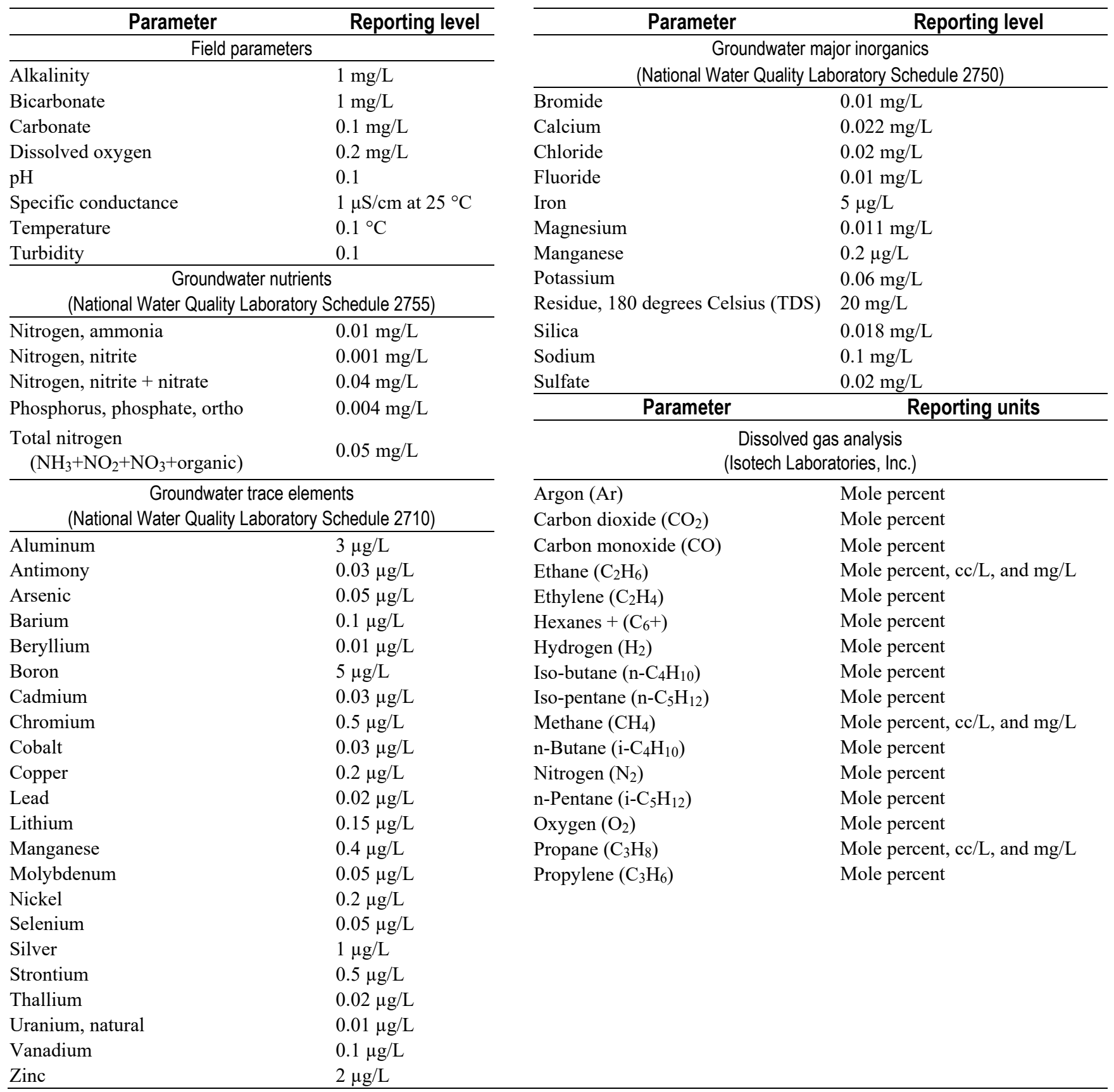




\section{Ammonia and Nitrate Concentration Trends Analysis Methods}

A Regional Kendall test (Helsel and others, 2006) was conducted to assess areal trends in ammonia and nitrate concentrations. The Regional Kendall is a nonparametric test for consistent regional trend across an area utilizing multiple sites. It evaluates a Mann-Kendall test for individual sampling sites and combines the results into one overall test for the regional trend (Helsel and Frans, 2006). Statistical power comparisons of the Seasonal Kendall test (which also applies to the Regional Kendall Test) with other trend tests determined that the Seasonal Kendall test is more powerful or nearly as powerful (96 percent) as other trend tests (Helsel and Frans, 2006). However, the Regional Kendall test is better in that it can directly use "non-detection" values because the test requires only a change between values and not the magnitude of change.

\section{Quality Assurance and Quality Control Methods}

All quality-assurance (QA) and quality-control (QC) samples were collected following protocols described in the USGS NFM (U.S. Geological Survey, variously dated). All water-quality samples (except those for dissolved gas analysis) were analyzed by the NWQL. The NWQL uses a Quality Management System (D.L. Stevenson, U.S. Geological Survey, unpub. data, 2013) and Quality Assurance and Quality Control Manual (D.L. Stevenson and A.R. Barnard, U.S. Geological Survey, unpub. data, 2013) as guidelines for the analytical work done at the laboratory. Isotech Laboratories does QA/QC using internal check standards and duplicates of submitted samples. The bias and precision of groundwater-quality sample results were evaluated through the collection of a field blank (except for dissolved gasses) and a sequential replicate sample.

\section{Results}

\section{Groundwater Levels}

Groundwater levels were only measured at 9 of the 15 wells due to access constraints in the other 6 wells, and a groundwater potentiometric surface and corresponding groundwater flow path were determined from the measurements (fig. 2). Previous studies by the IDEQ showed that groundwater flows in a northeasterly direction from the mountains in the south through the study area toward the Snake River (Idaho Department of Environmental Quality, 2018). The groundwater flow path direction in figure 2 matches that previously identified by the IDEQ (2018). 


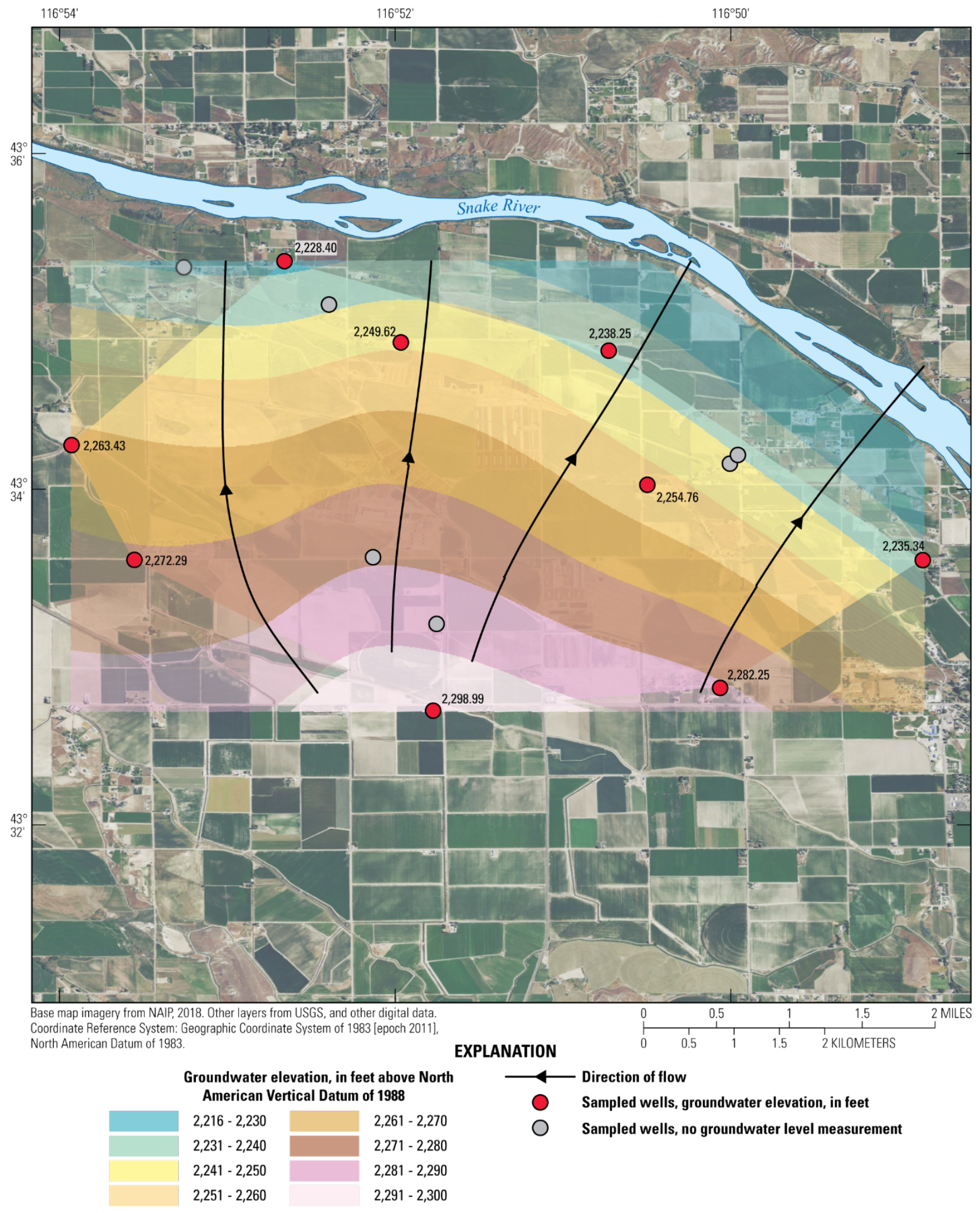

Figure 2. Map showing groundwater potentiometric surface and flow direction derived from nine groundwater-level measurements near Marsing, southwestern Idaho, 2018. Figure made by Christina Andry, Natural Resources Conservation Service. 


\section{Oxidation/Reduction State}

The oxidation/reduction (redox) state of groundwater can affect the concentration, transport, and fate of groundwater-quality constituents and can generate undesirable byproducts such as manganese, iron, hydrogen sulfide, and methane (Jurgens and others, 2009; McMahon and others, 2009). The redox state of groundwater is denoted by the dominant type of redox process occurring in the groundwaterquality sample and can vary locally by the type of dominant redox process such as dissolved oxygen, nitrate, manganese, iron, or sulfate. The groundwater-quality redox state was evaluated using the Microsoft ${ }^{\circledR}$ Excel $^{\circledR}$ workbook created by Jurgens and others (2009).

Groundwater oxidation/reduction conditions were anoxic in 11 of the 15 groundwater samples; 2 were oxic, 1 suboxic, and 1 mixed (anoxic) (table 2). The primary reduction process was Ferric iron/ $\mathrm{SO}_{4}{ }^{2-}$ in the anoxic samples. The anoxic water-quality state occurred throughout the study area (fig. 3 ), with no discernable spatial pattern for redox state or process. Oxic conditions occurred in two of the deeper wells; however, these conditions were inconsistent among other deep wells. Groundwater quality from two wells seemed to be experiencing mixing between the shallow and deep aquifers, as their redox states were either suboxic or mixed (anoxic) (table 2). 
Table 2. Oxidation/reduction (redox) state and predominant process, with selected groundwater-quality results from 15 wells near Marsing, southwestern Idaho, 2018.

[Shaded constituents are greater than U.S. Environmental Protection Agency secondary maximum contaminant levels. Abbreviations: mg/L, milligram per liter; $\mu \mathrm{g} / \mathrm{L}$, microgram per liter; $<$, less than]

\begin{tabular}{|c|c|c|c|c|c|c|c|c|c|}
\hline Well No. & $\begin{array}{l}\text { Well depth } \\
\text { (feet below } \\
\text { land surface) }\end{array}$ & $\begin{array}{c}\text { General } \\
\text { redox category }\end{array}$ & $\begin{array}{c}\text { Redox } \\
\text { process }\end{array}$ & $\begin{array}{l}\text { olved } \\
\text { gen } \\
\text { g/L) }\end{array}$ & $\begin{array}{l}\text { Iron } \\
(\mu \mathrm{g} / \mathrm{L})\end{array}$ & $\begin{array}{c}\text { Manganese } \\
(\mu \mathrm{g} / \mathrm{L})\end{array}$ & $\begin{array}{l}\text { Sulfate } \\
\text { (mg/L) }\end{array}$ & $\begin{array}{l}\text { Total } \\
\text { dissolved } \\
\text { solids } \\
\text { (mg/L) }\end{array}$ & Dissolved gas \\
\hline 433335116485101 & 142 & Anoxic & $\begin{array}{l}\mathrm{CH}_{4} \text { gen, } \\
\text { methanogenesis }\end{array}$ & $<0.01$ & 193 & 28 & 0.16 & 564 & \\
\hline 433449116504401 & 145 & Anoxic & $\begin{array}{l}\mathrm{CH}_{4} \text { gen, } \\
\text { methanogenesis }\end{array}$ & $<0.01$ & 309 & 54 & 0.13 & 538 & \\
\hline 433249116500301 & 144 & Anoxic & $\mathrm{Fe}(\mathrm{III}) / \mathrm{SO} 4$ & $<0.01$ & 4,180 & 687 & 624 & 1,350 & \\
\hline 433322116515601 & 164 & Anoxic & $\mathrm{Fe}(\mathrm{III}) / \mathrm{SO} 4$ & $<0.01$ & 2,030 & 158 & 239 & 648 & Sampled, methane detected \\
\hline 433335116533401 & 185 & Anoxic & $\mathrm{Fe}(\mathrm{III}) / \mathrm{SO} 4$ & $<0.01$ & 593 & 693 & 553 & 1,030 & Sampled, methane detected \\
\hline 433410116510201 & 80 & Anoxic & $\mathrm{Fe}(\mathrm{III}) / \mathrm{SO} 4$ & $<0.01$ & 465 & 136 & 37 & 529 & \\
\hline 433441116511201 & 120 & Anoxic & $\mathrm{Fe}(\mathrm{III}) / \mathrm{SO} 4$ & $<0.01$ & 290 & 265 & 228 & 659 & \\
\hline 433458116531401 & 42 & Anoxic & $\mathrm{Fe}(\mathrm{III}) / \mathrm{SO} 4$ & $<0.01$ & 108 & 36 & 4.3 & 492 & \\
\hline 433515116524601 & 130 & Anoxic & $\mathrm{Fe}(\mathrm{III}) / \mathrm{SO} 4$ & $<0.01$ & 198 & 197 & 132 & 516 & \\
\hline 433521116524001 & 117 & Anoxic & $\mathrm{Fe}(\mathrm{III}) / \mathrm{SO} 4$ & $<0.01$ & 445 & 101 & 28 & 509 & \\
\hline 433416116535601 & 200 & Anoxic & Mn(IV) & $<0.01$ & 45.0 & 202 & 156 & 511 & Sampled, methane detected \\
\hline 433241116514601 & 130 & Mixed (anoxic) & $\mathrm{NO}_{3}-\mathrm{Fe}(\mathrm{III}) / \mathrm{SO} 4$ & $<0.01$ & 142 & 275 & 300 & 798 & \\
\hline 433402116503201 & 256 & Suboxic & Suboxic & $<0.01$ & 61.7 & 38.2 & 12 & 689 & $\begin{array}{l}\text { Sampled, ethane detected and } \\
\text { elevated concentrations of } \\
\text { methane }\end{array}$ \\
\hline 433349116510301 & 184 & Oxic & $\mathrm{O}_{2}$ & 3.61 & $<10.0$ & $<0.40$ & 64 & 554 & \\
\hline 433422116511601 & 530 & Oxic & $\mathrm{O}_{2}$ & 4.09 & 15.6 & 7.04 & 403 & 1,260 & Sampled, methane detected \\
\hline
\end{tabular}




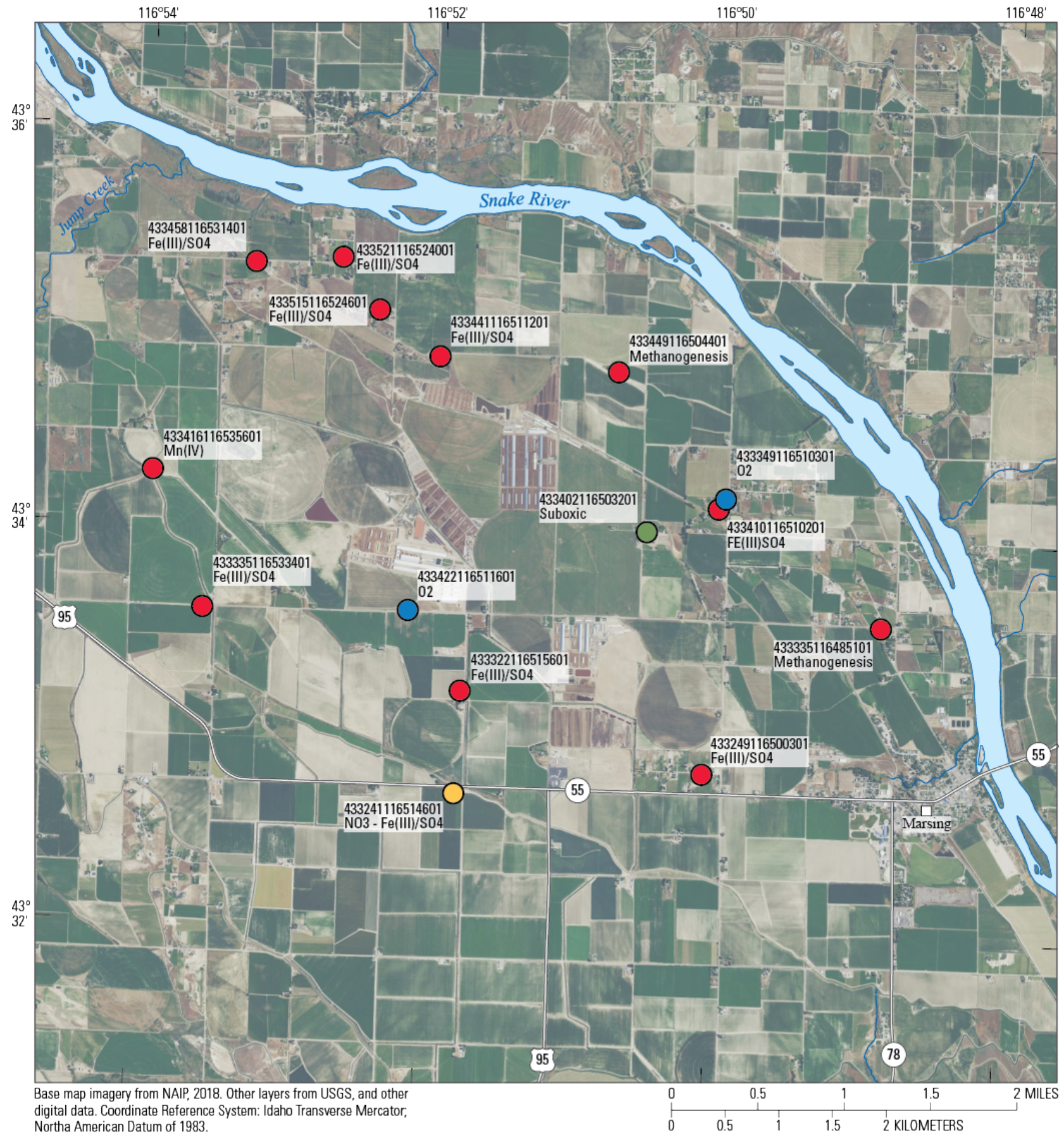

EXPLANATION

Groundwater-quality sampling location with station identification number and redox type

Anoxic
Mixed (anoxic)
Suboxic
Oxic

Figure 3. Map showing groundwater-quality sampling locations with site identification numbers and oxidation/reduction process and type for 15 wells near Marsing, southwestern Idaho, 2018. 


\section{Trace Elements}

Arsenic

Arsenic is a nonmetallic trace element with natural geologic sources and is used in some pesticides and industrial activities. Long-term exposure to arsenic in drinking water can result in skin damage or circulatory system problems, as well as increased risk of cancer of the skin, bladder, liver, kidney, nasal passages, prostate, and lungs (U.S. Environmental Protection Agency, 2018a). The EPA MCL for arsenic is 10 micrograms per liter $(\mu \mathrm{g} / \mathrm{L})$ or parts per billion. Elevated arsenic concentration in groundwater are related to complex geochemical conditions in the aquifer. The most common cause of elevated arsenic concentrations in groundwater is the release of arsenic from iron oxides in the aquifer materials (Welch and others, 2000). Other causes of elevated arsenic concentrations are low dissolved oxygen (anoxic redox conditions), high $\mathrm{pH}$ (alkaline conditions), and arsenic being concentrated by evaporation (Ayotte and others, 2011).

All 15 water-quality samples had mid-range $\mathrm{pH}$ values (between 7 and 8), and 13 of the 15 samples had no dissolved oxygen. The redox state of the 15 water-quality samples varied from anoxic to oxic conditions. Concentrations of total dissolved solids, silica, and alkalinity varied with the arsenic concentrations in the 15 water-quality samples, indicating that arsenic occurrence is not related to geochemical changes resulting from evaporative concentration (Welch and others, 2000).

Seven of the 15 wells sampled for arsenic had concentrations greater than the EPA MCL of 10

$\mu \mathrm{g} / \mathrm{L}$ (11.2-33.8 $\mu \mathrm{g} / \mathrm{L}$; fig. 4). Arsenic concentrations do not appear to be related spatially, to well depth, or to other water-quality constituents. 


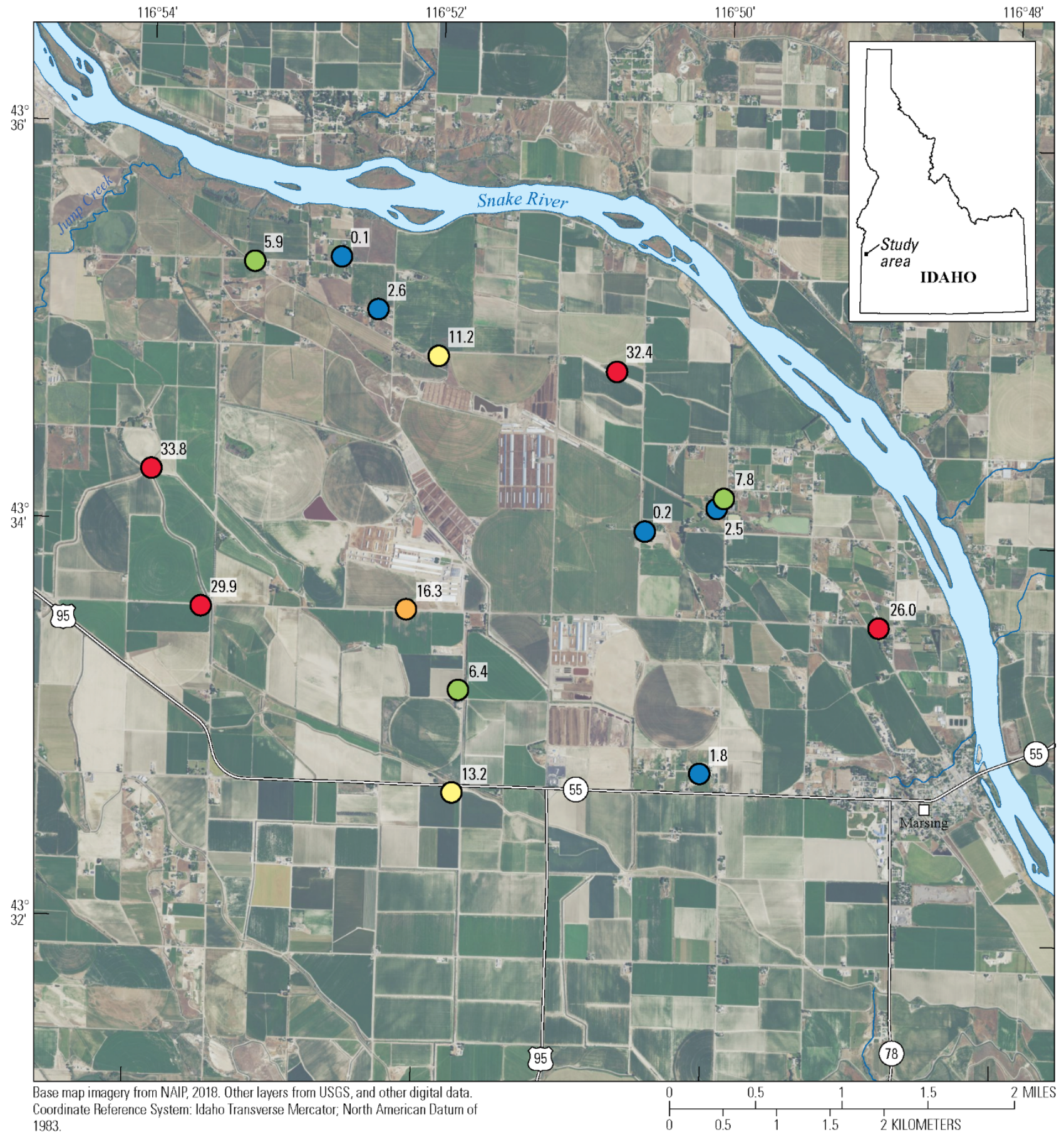

\section{EXPLANATION}

Arsenic, in micrograms per liter

$0.1-5.0$
$5.1-10.0$
$10.1-15.0$
$15.1-20.0$
$20.1-33.8$

Figure 4. Arsenic concentrations from 15 water-quality samples collected from wells near Marsing, southwestern Idaho, 2018. 
Iron and Manganese

For several water-quality constituents, the EPA has secondary drinking water standards to account for aesthetic qualities of drinking water such as taste and odor. These SMCLs are not considered a risk to human health. Effects of both iron and manganese at concentrations greater than the SMCL are a metallic taste to the drinking water and staining of items in contact with the water (U.S. Environmental Protection Agency, 2018b).

Concentrations of both iron and manganese exceeded SMCLs in water-quality samples collected for this study. Iron concentrations were greater than the SMCL of $300 \mu \mathrm{g} / \mathrm{L}$ in 6 of the 15 samples, with concentrations from 16 to $4,180 \mu \mathrm{g} / \mathrm{L}$, more than 6 times the SMCL (table 2). Manganese concentrations were greater than the SMCL of $50 \mu \mathrm{g} / \mathrm{L}$ in 10 of the 15 samples, with concentrations from 7 to $693 \mu \mathrm{g} / \mathrm{L}$, more than 13 times the SMCL (table 2).

\section{Sulfate and Total Dissolved Solids}

Along with iron and manganese, sulfate and total dissolved solids (TDS) have SMCLs established by the EPA. Effects of both sulfate and TDS greater than the SMCL are a salty taste to drinking water; TDS concentrations greater than the SMCL also result in high hardness of water, deposits on plumbing fixtures, and staining of items in contact with the water. Sulfate concentrations were greater than the SMCL of $250 \mathrm{mg} / \mathrm{L}$ in 4 of the 15 samples, with concentrations from 0.13 to 624 $\mathrm{mg} / \mathrm{L}$, more than double the SMCL. TDS concentrations were greater than the SMCL of $500 \mathrm{mg} / \mathrm{L}$ in 14 of the 15 samples, with concentrations from 492 to $1,350 \mathrm{mg} / \mathrm{L}$, more than double the SMCL (table 2).

\section{Piper Plots}

The groundwater-quality samples were characterized by a piper plot (trilinear diagram), which visualizes the relative abundance of ions in groundwater. Groundwater quality samples with similar chemistry tend to plot in groups. The group location within the piper plot provides the description of the chemical composition of the water; for example, a sodium-bicarbonate type water plots close to the bottom corner of the central diamond shape (Winston, 2000; Appelo and Postma, 2004). The piper plot identified two wells with calcium bicarbonate water, five wells with sodium bicarbonate water, and eight wells with calcium sulfate water (fig. 5). However, the piper plot groupings do not correlate with well depth or any of the groundwater quality parameters of interest discussed in other sections. 


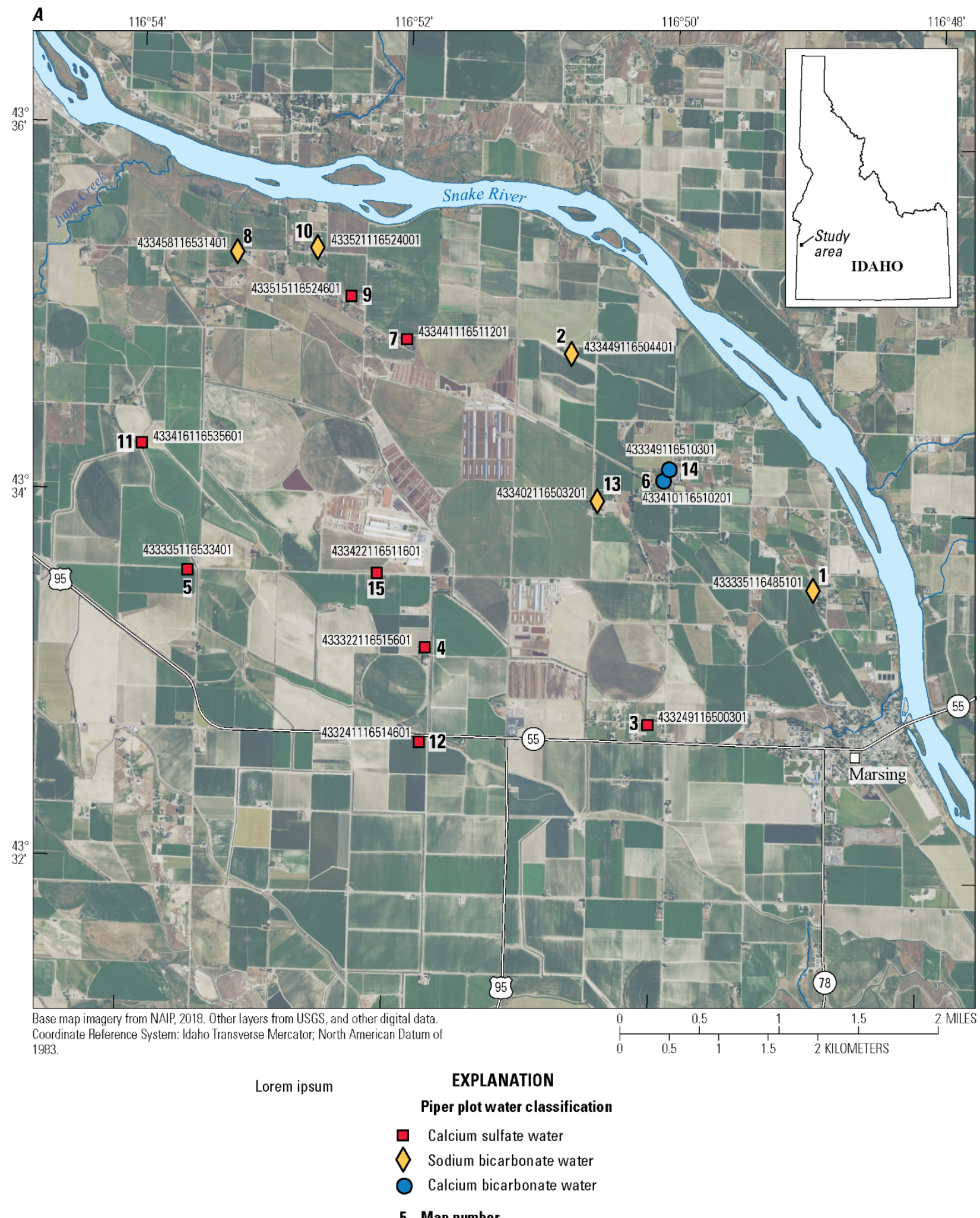

Figure 5. Map $(A)$ and piper plot $(B)$ of 15 groundwater-quality samples collected near Marsing, southwestern Idaho, 2018. 


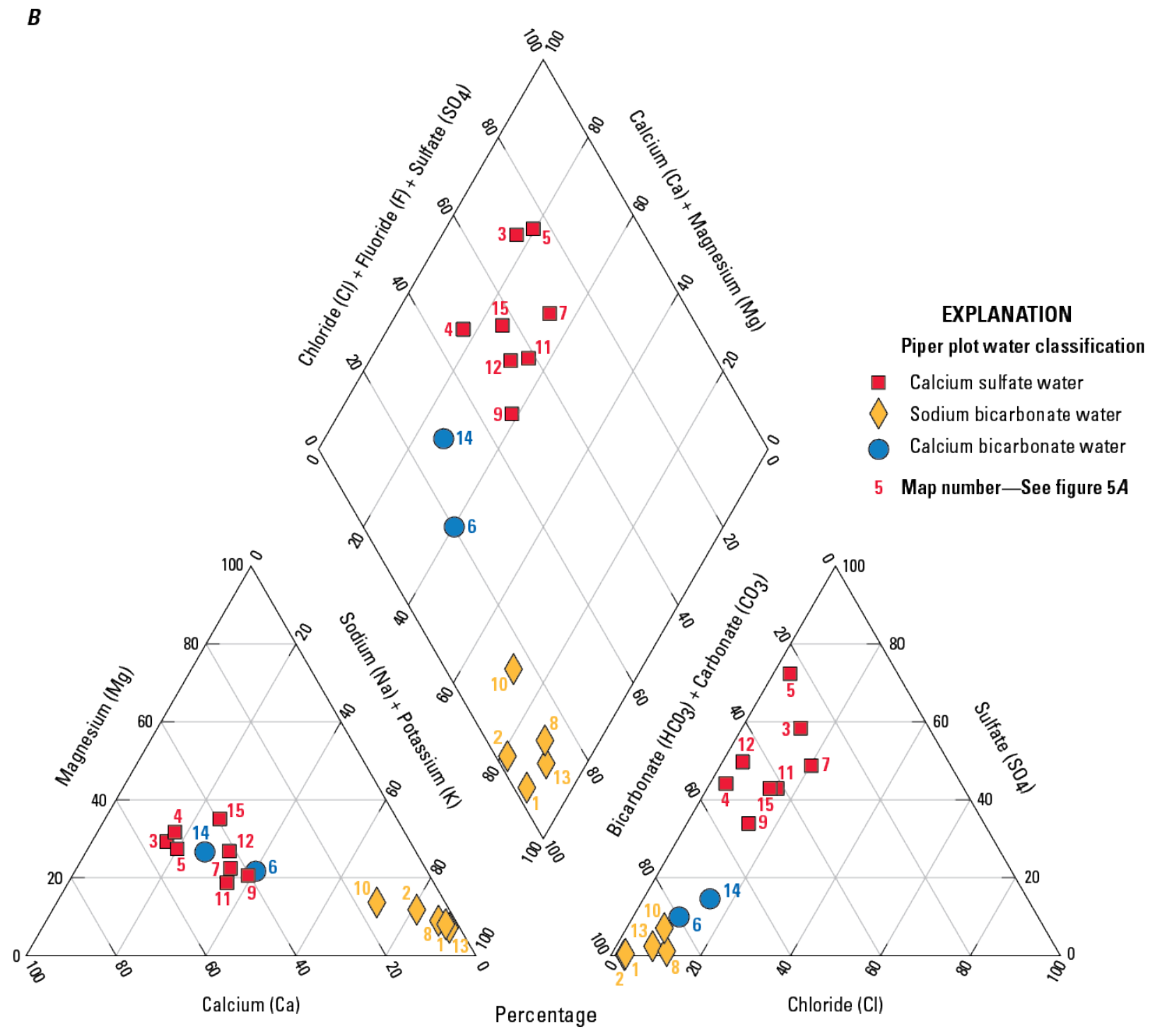

Figure 5.-Continued.

\section{Dissolved Gases}

Five groundwater-quality samples were collected for dissolved gases, including percent composition of argon, oxygen, carbon dioxide, helium, dinitrogen, carbon monoxide, methane, and higher-chain hydrocarbons (table 1). All five dissolved-gas samples had mole percentages of argon, oxygen, carbon dioxide, dinitrogen, and methane gas. One sample also contained ethane. Four of the five dissolved gas samples had methane concentrations below $0.015 \mathrm{mg} / \mathrm{L}$, but one sample from well 433402116503201 had a methane concentration of $41 \mathrm{mg} / \mathrm{L}$. The dissolved gas sample with the elevated methane concentration also contained the one detection of ethane $(0.0032 \mathrm{mg} / \mathrm{L})$. The EPA has not established a MCL for methane, but the U.S. Office of Surface Mining action level for dissolved methane is $28 \mathrm{mg} / \mathrm{L}$ (Eltschlager and others, 2001). U.S. Office of Surface Mining indicates that methane concentrations greater than $28 \mathrm{mg} / \mathrm{L}$ result in potentially explosive or flammable quantities of gas being degassed from the water. 


\section{Nutrients}

Nutrients in groundwater were of specific interest in this study because of the predominance of agriculture in the study area and evaluations of nutrients in previous studies (1999-2009) (Bahr, 2009; Idaho Department of Environmental Quality, 2018). While the production of most crops grown in Owyhee County have remained stable from 2002 to 2012, corn production has increased four-fold, and milk output from dairies has more than tripled (U.S. Department of Agriculture, 2018). These increases result in increased application of nutrients for crops and increased nutrients from dairy cattle. The form of nutrients observed in the groundwater samples depends on the oxidation/reduction conditions within the aquifer. Ammonia occurs in a reducing environment since oxygen is not present to facilitate nitrification (the conversion of ammonium to nitrate by bacteria).

Fourteen of the 15 nutrient samples contain ammonia, and 6 of the 15 nutrient samples contain nitrate (fig. 6). The presence of both ammonia and nitrate in four samples with no dissolved oxygen indicates multiple nutrient sources, because nitrification cannot occur without dissolved oxygen. One nitrate concentration $(24 \mathrm{mg} / \mathrm{L})$ was greater than the EPA MCL of $10 \mathrm{mg} / \mathrm{L}$ for drinking water and was also collected from the deepest well sampled. The EPA has not established a MCL for ammonia in drinking water. Ammonia concentrations increase downgradient toward the Snake River through the study area. 


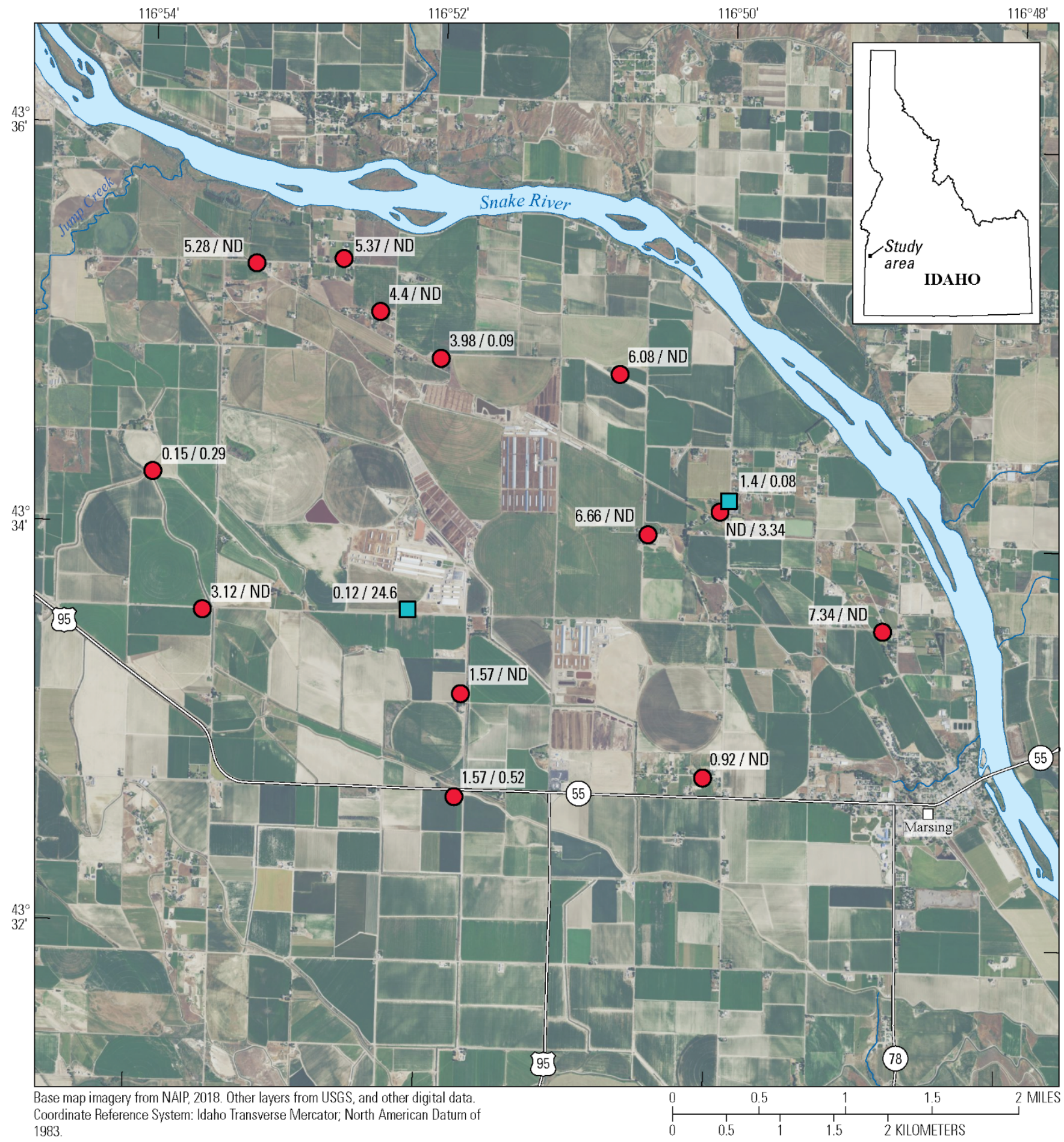

EXPLANATION

Dissolved oxygen, in milligrams per liter

Absent, ammonia / nitrate; ND = not detected

Present, ammonia / nitrate; ND = not detected

Figure 6. Map showing dissolved oxygen presence and nutrient type in groundwater-quality samples from 15 wells near Marsing, southwestern Idaho, 2018. 


\section{Trends Analysis}

\section{Selection of Nutrient Trends Concentration Data}

Ammonia and nitrate concentration trends were evaluated from groundwater-quality samples from individual wells and for the entire study area. Water-quality data for ammonia and nitrate were compiled from ISDA, IDEQ, and the USGS National Water Information System databases. Waterquality data were filtered to include only samples collected nearest to the sampling month of this study (March and April). Eleven of the 15 sampled wells had sufficient prior water-quality data to evaluate trends at each well. One of the wells with water-quality data did not have enough ammonia concentrations above the laboratory detection limit to evaluate a trend. The same was true for nitrate concentrations from 7 of the 11 wells. Regional nutrient water-quality data are available for 1996-2018, with a varying amount of data available for each well. The Regional Kendall test input concentration data applied a similar data restriction used for the individual well trend tests (samples collected in the spring); however, all available well locations in the Marsing area were used, including the 2018 sampling done for this study.

\section{Nutrient Trends Results}

Eight of the wells with ammonia concentrations showed no temporal trend. Two of the wells with nitrate concentrations also showed no trend. Well 433349116510301 indicated an increasing trend in nitrate concentration from 1999 to 2018 (table 3), Mann-Kendall test p-value 0.009. Well 433422116511601 also had an increasing trend in nitrate concentrations (Mann-Kendall test p-value 0.056), but not statistically significant trends for ammonia concentrations for the period of record (2000-18), even though ammonia concentrations are decreasing since 2003 (fig. 7). The increase of nitrate and decrease of ammonia concentrations could occur from an increase of dissolved oxygen concentrations or a change of nutrient input from the surface. Ammonia concentrations from well 433335116533401 do not indicate a statistically significant trend for all samples, 1999-2018, but have increasing concentrations since 2002. Seasonal effects are not present in the trend analysis because all samples were collected during spring. Also, trend analysis did not account for possible climatic affects, such as droughts or floods. 
Table 3. Ammonia and nitrate trend evaluations from water-quality samples collected at 15 wells near Marsing, southwestern, Idaho, 2018.

\begin{tabular}{|c|c|c|c|}
\hline Well No. & Site name & Ammonia trend evaluation & Nitrate evaluation \\
\hline 433335116485101 & 03N 04W 33AAA1 & No trend & $\begin{array}{l}\text { Concentrations below laboratory } \\
\text { detection limit }\end{array}$ \\
\hline 433449116504401 & 03N 04W 20CAB1 & No trend & $\begin{array}{l}\text { Concentrations below laboratory } \\
\text { detection limit }\end{array}$ \\
\hline 433249116500301 & 03N 04W 32DDD1 & Insufficient data for analysis & Insufficient data for analysis \\
\hline 433322116515601 & 03N 04W 31BDD1 & No trend & $\begin{array}{l}\text { Concentrations below laboratory } \\
\text { detection limit }\end{array}$ \\
\hline 433335116533401 & 03N 05W 35AAA1 & Increasing concentrations & $\begin{array}{l}\text { Concentrations below laboratory } \\
\text { detection limit }\end{array}$ \\
\hline 433410116510201 & 03N 04W 29ADA2 & Insufficient data for analysis & Insufficient data for analysis \\
\hline 433441116511201 & 03N 04W 19CAB1 & No trend & $\begin{array}{l}\text { Concentrations below laboratory } \\
\text { detection limit }\end{array}$ \\
\hline 433458116531401 & 03N 05W 24BBA1 & No trend & $\begin{array}{l}\text { Concentrations below laboratory } \\
\text { detection limit }\end{array}$ \\
\hline 433515116524601 & 03N 05W 24ADA1 & No trend & $\begin{array}{l}\text { Concentrations below laboratory } \\
\text { detection limit }\end{array}$ \\
\hline 433521116524001 & 03N 05W 13DCD1 & Insufficient data for analysis & Insufficient data for analysis \\
\hline 433416116535601 & 03N 05W 26ABC1 & No trend & No trend \\
\hline 433241116514601 & 02N 04W 06BAA1 & No trend & No trend \\
\hline 433402116503201 & 03N 04W 29DBB1 & Insufficient data for analysis & Insufficient data for analysis \\
\hline 433349116510301 & 3N 04W 29ADA1 & $\begin{array}{l}\text { Concentrations below } \\
\text { laboratory detection limit }\end{array}$ & $\begin{array}{l}\text { Statistically significant } \\
\text { increasing trend }\end{array}$ \\
\hline 433422116511601 & 03N 04W 30CCD2 & Decreasing concentrations & $\begin{array}{l}\text { Statistically significant } \\
\text { increasing trend }\end{array}$ \\
\hline
\end{tabular}



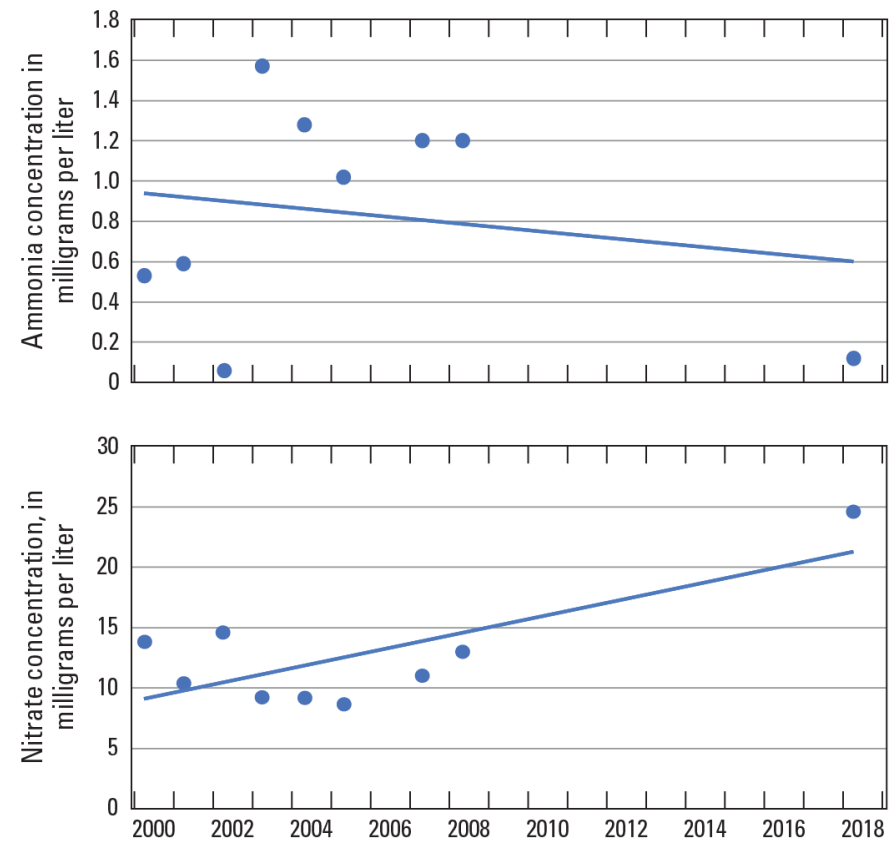

Figure 7. Graphs showing ammonia and nitrate concentrations from water-quality samples collected at well 433422116511601 near Marsing, southwestern Idaho, 2018.

The Regional Kendall Test for ammonia trends analyzed 539 ammonia concentrations from 91 wells over 20 years (1999-2018). The Regional Kendall Test for ammonia resulted in no significant regional trend with a tau correlation coefficient of -0.073 and a p-value of 0.072 . The Regional Kendall Test for nitrate trends analyzed 591 nitrate concentrations from 107 wells over 23 years (1996-2018). The Regional Kendall test for nitrate resulted in no significant regional trend with a tau correlation coefficient of -0.041 and a p-value of 0.198 .

\section{Quality Assurance and Quality Control Results}

The field blank resulted in non-detections for all constituents except silica and ammonia. Field blank detections for silica and ammonia were slightly greater than the detection limits. The silica concentration was $0.025 \mathrm{mg} / \mathrm{L}$, which is $0.007 \mathrm{mg} / \mathrm{L}$ greater than the detection level of $0.018 \mathrm{mg} / \mathrm{L}$, indicating an insignificant bias considering silica concentrations in the 15 water-quality samples were $42-79 \mathrm{mg} / \mathrm{L}$. The ammonia concentration was 0.02 , which is $0.01 \mathrm{mg} / \mathrm{L}$ greater than the detection limit of $0.01 \mathrm{mg} / \mathrm{L}$. The low concentration ammonia detection is likely due to laboratory method processes and not field procedures (Fulford, 2018). The ammonia concentrations in the water-quality samples range from a non-detection to $9.5 \mathrm{mg} / \mathrm{L}$, indicating a minimal bias for small ammonia concentrations.

The sequential replicate sample was collected on the same date as the field blank. The constituents with the highest relative percent differences (Mueller and others, 2015) between the original water-quality sample and the sequential replicate sample were (1) lead, 84 percent, sample and replicate concentrations of 0.14 and $0.06 \mu \mathrm{g} / \mathrm{L}$; (2) copper, 48 percent, sample and replicate concentrations of 2.5 and $4.0 \mu \mathrm{g} / \mathrm{L}$; (3) zinc 39 percent, sample and replicate concentrations of 2.0 and $3.0 \mu \mathrm{g} / \mathrm{L}$; (4) carbonate 18 percent, sample and replicate concentrations of 0.6 and $0.5 \mathrm{mg} / \mathrm{L}$; (5) nickel, 14 percent, sample and replicate concentrations of 0.52 and $0.45 \mu \mathrm{g} / \mathrm{L}$; and (6) cobalt, 9 percent, sample and replicate concentrations of 0.049 and $0.045 \mu \mathrm{g} / \mathrm{L}$. The elevated relative percent differences of these six constituents have minimal impact on the trends analysis because these constituents are of minimal importance given the scope of the study. 
For all other constituents, the replicate analysis yielded values that were less than 5 percent difference between the original field sample and sequential replicate sample, or the constituents were at concentrations less than the laboratory reporting levels hence not comparable.

\section{Summary}

The U.S. Geological Survey, in cooperation with the Idaho Department of Environmental Quality, sampled groundwater for field parameters, nutrients, trace elements, major inorganics, and dissolved gas, including methane from 15 wells during spring 2018 near the city of Marsing in rural northwestern Owyhee County, southwestern Idaho. Groundwater levels were measured at 9 of the 15 wells from which a groundwater potentiometric surface map and corresponding flow paths were determined. Groundwater-quality samples were characterized by piper plots and evaluated for oxidation/reduction status and type. Ammonia and nitrate trends were also performed at individual wells and for the region.

Groundwater-flow paths confirmed previous direction findings. Piper plots identified three groundwater chemistry types. Groundwater oxidation/reduction (redox) conditions were anoxic in 11 of 15 the groundwater samples; 2 were oxic, 1 suboxic, and 1 mixed (anoxic). The redox condition of groundwater can affect the concentration, transport, and fate of groundwater-quality constituents and generate undesirable byproducts such as manganese, iron, hydrogen sulfide, and methane. The anoxic redox condition occurs throughout the study area with no discernable spatial pattern or depth relationship for redox condition or process.

Groundwater-quality contaminants of interest include arsenic where 7 of the 15 wells sampled had concentrations greater than the EPA MCL of $10 \mu \mathrm{g} / \mathrm{L}$. Arsenic concentrations ranged from 11.2 to $33.8 \mu \mathrm{g} / \mathrm{L}$ in samples from these 7 wells. Many groundwater-quality samples from wells had contaminants greater than the EPA SMCLs, which are not considered to be a risk to human health but affect the aesthetic qualities of drinking water such as taste and odor and can cause staining of items in contact with the water. Water-quality samples from the 15 wells were greater than the SMCL for iron (6 samples with concentrations from 16 to $4,180 \mu \mathrm{g} / \mathrm{L})$, manganese (10 samples with concentrations from 7 to $693 \mu \mathrm{g} / \mathrm{L}$ ), sulfate (4 samples with concentrations from 0.13 to $624 \mathrm{mg} / \mathrm{L}$ ), and total dissolved solids (14 samples with concentrations from 492 to $1,350 \mathrm{mg} / \mathrm{L}$ ).

Groundwater-quality nutrient analyses shows that 14 of the 15 samples contain ammonia, and 6 of the 15 nutrient samples have nitrate with 1 nitrate sample $(24 \mathrm{mg} / \mathrm{L})$ exceeding the EPA maximum contaminant level of $10 \mathrm{mg} / \mathrm{L}$ for drinking water. The presence of both ammonia and nitrate in four samples with no dissolved oxygen indicates multiple nutrient sources as nitrification cannot occur without dissolved oxygen. Ammonia concentrations increase downgradient toward the Snake River through the study area. Nitrate concentrations do not have a spatial trend in the study area.

Nutrient trend analyses evaluated water-quality data for the months of March and April for the period 1996 to 2018 and identified an increasing trend in nitrate concentration from water-quality samples from one well (Mann-Kendall test p-value 0.009). Water-quality samples from another well do not have statistically significant trends but have increasing nitrate concentrations since 2005 and have decreasing ammonia concentrations since 2003. For all other wells, water-quality samples do not indicate the presence of a temporal trend. The Regional Kendall test indicated no significant regional trends for either ammonia or nitrate, p-values of 0.072 and 0.198 , respectively. 


\section{Acknowledgments}

This study would not have been possible without the cooperation of well owners in the area. Access to their wells is essential for collecting groundwater-quality samples. The author would also like to thank Christina Andry of the U.S. Department of Agriculture Natural Resources Conservation Service who assisted with collection of the groundwater-quality samples and analyzed groundwater levels to create the groundwater-flow map shown in figure 2.

\section{References Cited}

Appelo, C.A.J., and Postma, D., 2004, Geochemistry, groundwater and pollution: CRC Press, 668 p. Ayotte, J.D., Gronberg, J.M., and Apodaca, L.E., 2011, Trace elements and radon in groundwater across the United States, 1992-2003: U.S. Geological Survey Scientific Investigations Report 2011-5059, 115 p., accessed May 15, 2018, at https://pubs.usgs.gov/sir/2011/5059/.

Bahr, G., 2009, Ground water quality of northern Owyhee County aquifers: Boise, Idaho State Department of Agriculture Technical Results Summary \# 42, 20 p., accessed May 15, 2018, at http://www.idahoag.us/agri/Categories/Environment/water/waterPDF/gwreports/NorthOwyhee_Repor t_April_2009_Final_Draft.pdf.

Boyle, L., Carlson, R., and Bahr, G., 2002, 2001 annual ground water quality monitoring summary results for northwest Owyhee County, Idaho: Boise, Idaho State Department of Water Quality, 38 p., accessed November 6, 2017, at http://www.deq.idaho.gov/media/474027_water_data_reports_ground_water_owyhee_county_monitoring.pdf.

Cunningham, W.L., and Schalk, C.W., comps., 2011, Groundwater technical procedures of the U.S. Geological Survey: U.S. Geological Survey Techniques and Methods 1-A1, 151 p., accessed March 3, 2018, at https://pubs.usgs.gov/tm/1a1/.

Eltschlager, K.K., Hawkins, J.W., Ehler, W.C., and Baldassare, Fred, 2001, Technical measures for the investigation and mitigation of fugitive methane hazards in areas of coal mining: Pittsburgh, Office of Surface Mining Reclamation and Enforcement, 124 p., accessed July 18, 2018, at https://www.osmre.gov/resources/library/ghm/methane.pdf.

Fulford, J., 2018, Low-level detections of ammonia in surface-water field-blank samples: Water Mission Area Technical Note Number 18, accessed July 18, 2018, at https://sites.google.com/a/usgs.gov/wmawiki/news/technote/18.

Helsel, D.R., and Frans, L.M., 2006, Regional Kendall Test for trend: Environmental Science \& Technology, v. 40, no. 13, 8 p., https://doi.org/10.1021/es051650b.

Helsel, D.R., Mueller, D.K., and Slack, J.R., 2006, Computer program for the Kendall family of trend tests: U.S. Geological Survey Scientific Investigations Report 2005-5272, 4 p., accessed June 16, 2018, at https://pubs.usgs.gov/sir/2005/5275/.

Idaho Department of Environmental Quality, 2010, Owyhee County ground water quality improvement and drinking water source protection plan: Boise, Idaho Department of Environmental Quality, 229 p., accessed November 6, 2017, at http://www.deq.idaho.gov/media/473984_water_data_reports_ground_water_owyhee_co_gwq_dwsp_plan.pdf.

Idaho Department of Environmental Quality, 2018, Owyhee County ground water quality improvement and drinking water source protection plan: Idaho Department of Environmental Quality, accessed August 3, 2018, at http:/www.deq.idaho.gov/media/60181879/owyhee-county-ground-water-qualityimprovement-drinking-water-source-protection-plan.pdf.

Jurgens, B.C., McMahon, P.B., Chapelle, F.H., and Eberts, S.M., 2009, An Excel ${ }^{\circledR}$ workbook for identifying redox processes in ground water: U.S. Geological Survey Open-File Report 2009-1004, 8 p., accessed August 3, 2018, at http://pubs.usgs.gov/of/2009/1004/. 
Link, P.K., 2002, Digital atlas of Idaho: Pocatello, Idaho State University, Geosciences Department, accessed June 28, 2018, at https://imnh.iri.isu.edu/digitalatlas/counties/geomaps/geomap.htm.

McMahon, P.B., Cowdery, T.K., Chapelle, F.H., and Jurgens, B.C., 2009, Redox conditions in selected Principal Aquifers of the United States: U.S. Geological Survey Fact Sheet 2009-3041, 6 p., accessed June 28, 2018 at https://pubs.usgs.gov/fs/2009/3041/.

Mueller, D.K., Schertz, T.L., Martin, J.D., and Sandstrom, M.W., 2015, Design, analysis, and interpretation of field quality-control data for water-sampling projects: U.S. Geological Survey Techniques and Methods, book 4, chap. C4, 54 p., http://dx.doi.org/10.3133/tm4C4.

U.S. Department of Agriculture National Agricultural Statistics Service, 2018, CropScape-Cropland data layer: U.S. Department of Agriculture, accessed June 3, 2018, at https://nassgeodata.gmu.edu/CropScape/.

U.S. Department of Agriculture National Agricultural Statistics Service, 2018, Quick stats: U.S. Department of Agriculture National Agriculture Statistics Service, accessed August 28, 2018, at https://quickstats.nass.usda.gov/

U.S. Environmental Protection Agency, 2018a, Drinking water requirements for states and public water systems - Chemical contaminant rules: U.S. Environmental Protection Agency, accessed June 3, 2018, at https://www.epa.gov/dwreginfo/chemical-contaminant-rules.

U.S. Environmental Protection Agency, 2018b, Secondary drinking water standards: Guidance for nuisance chemicals, accessed August 14, 2018, at https://www.epa.gov/dwstandardsregulations/secondary-drinking-water-standards-guidance-nuisancechemicals.

U.S. Geological Survey, variously dated, National field manual for the collection of water-quality data: U.S. Geological Survey Techniques of Water-Resources Investigations, book 9, chaps. A1-A10, accessed January 18, 2018, at http://pubs.water.usgs.gov/twri9A.

Welch, A.H., Westjohn, D.B., Helsel, D.R., and Wanty, R.B., 2000, Arsenic in ground water of the United States-Occurrence and geochemistry: Ground Water, v. 38, no. 4, p. 589-604 https://doi.org/10.1111/j.1745-6584.2000.tb00251.x.

Wilde, F.D., ed., 2006, Collection of water samples (version 2.0): U.S. Geological Survey Techniques of Water-Resources Investigations, book 9, chap. A4, section 4.2.3., 5 p., accessed December 18, 2017, at http://pubs.water.usgs.gov/twri9A4/.

Winston, R.B., 2000, Graphical user interface for MODFLOW-GUI, version 4: U.S. Geological Survey Open-File Report 00-315, 27 p., accessed December 18, 2017, at https://water.usgs.gov/nrp/gwsoftware/mfgui4/modflow-gui.html. 
This page intentionally left blank. 
Publishing support provided by the U.S. Geological Survey Science Publishing Network, Tacoma Publishing Service Center

For more information concerning the research in this report, contact the Director, Idaho Water Science Center

U.S. Geological Survey

230 Collins Rd

Boise, Idaho 83702-4520

https://www.usgs.gov/centers/id-water 
